\title{
Child Ability and Household Human Capital Investment Decisions in Burkina Faso
}

\author{
RICHARD AKRESH \\ University of Illinois at Urbana-Champaign \\ EMILIE BAGBY \\ Mathematica Policy Research \\ DAMIEN DE WALQUE \\ World Bank
}

HAROUNAN KAZIANGA

Oklahoma State University

\section{Introduction}

Parents' decisions about whether and how much to invest in their children's human capital depend on many factors, and these decisions have long-lasting impacts on each child's future earnings, marital prospects, and overall welfare. A large literature attempts to understand the source of inequalities for children's educational investments within a household building on seminal work by Becker and Tomes (1976) that delineates the trade-off between the quantity of children and their "quality." In making the schooling investment decision, parents will have information about a child's ability, and that information will

These data were collected for a project evaluating social protection strategies in Burkina Faso, which greatly benefited from the support of Marie-Claire Damiba, Seydou Kabré, and Victorine Yameogo from the Secrétariat Permanent du Comité National de Lutte contre le SIDA et les Infections Sexuellement Transmissibles in Burkina Faso and Hans Binswanger, Nono Ayivi-Guedehoussou, Ousmane Haidara, Timothy Johnston, Mead Over, and Tshiya Subayi-Cuppen at the World Bank. Data collection was supervised by Robert Ouedraogo, Jean-Pierre Sawadogo, Bambio Yiriyibin, and Pam Zahonogo from the University of Ouagadougou, Department of Economics. The project is funded by the National Bureau of Economic Research Africa Project and the following World Bank trust fund grants: Strategic Impact Evaluation Fund, Bank-Netherlands Partnership Program, Gender Action Plan, Knowledge for Change Program, and Luxembourg Poverty Reduction Partnership. We would also like to thank German Caruso for research assistance and two anonymous reviewers, Harold Alderman, Kathy Baylis, Eric Edmonds, Don Fullerton, Craig Gundersen, Christopher Ksoll, Nolan Miller, Elizabeth Powers, and participants at the T. Paul Schultz festschrift conference and seminars at the University of Illinois at Urbana-Champaign for helpful comments on earlier drafts. The findings, interpretations, and conclusions expressed in this article are entirely ours. They do not represent the views of the World Bank, its executive directors, or the countries they represent.

(c) 2012 by The University of Chicago. All rights reserved. 0013-0079/2012/6101-0007\$10.00 
often not be available to researchers, which partly explains why much of the empirical research on the determinants of household investments in children's schooling focuses on easy to observe demographic characteristics of the child such as gender, birth order, and family composition (Parish and Willis 1993; Garg and Morduch 1998; Black, Devereux, and Salvanes 2005). ${ }^{1}$ More recent papers attempt to use direct measurements of a child's ability such as IQ scores (Kim 2005) or cognitive tests (Ayalew 2005) to better understand which factors influence investment decisions.

In this article, we build on the seminal work by Rosenzweig and Schultz (1982) to examine the role that a child's cognitive ability plays in a resourceconstrained household's decision to invest in that child's education. For poor households trying to maximize the returns to their human capital investments, schooling decisions will depend on parents' perceptions about the returns to school for a given child and that child's ability. Few households in rural Burkina Faso ever enroll all of their children in school (in our data only $27 \%$ do so). In such a setting, understanding the link between child ability and school enrollment and school continuation decisions is critical for developing policy prescriptions to improve educational outcomes.

We make four main contributions to the literature on explaining household school investment decisions. First, we employ direct measures of a child's ability for all children of primary school age (5-15), regardless of whether they are currently enrolled in school. This differs from existing studies that tend to have ability measures only for children who are currently enrolled in school (Glick and Sahn 2010). We use the Raven's Colored Progressive Matrices (CPM) and the Wechsler Intelligence Scales (WISC) Digit Span as measures of a child's cognitive ability. Second, our study is unique in explicitly incorporating direct measures of the ability of each child's siblings (both absolute and relative measures) and to show how sibling ability "rivalry" exerts a strong impact on the parents' decision of which child to send to school. Such rivalry could explain the high level of variation in enrollment across siblings within a family that we observe in our data and in rural Burkina Faso in general. Third, the survey instrument asks parents to provide their perceptions about the likely chances of future economic success for each of their children, information that is not often gathered in surveys. We show that a similar pattern of sibling rivalry is observed using either these parent perceptions or the externally validated

\footnotetext{
1 See Strauss and Thomas (1995) and Glewwe and Kremer (2006) for reviews of the literature. Related research explores the relationship between these demographic characteristics and the nonschooling outcomes of employment (Kessler 1991), risky behaviors (Aizer 2004), and child labor (Emerson and Souza 2008).
} 
cognitive ability tests measuring child ability. Fourth, we address potential endogeneity concerns about schooling influencing measures of child ability by exploiting the panel data structure and focusing on the relationship between the enrollment decision in the survey's second year and the ability measures observed in the survey's first year for the subset of young children who were not enrolled and not yet of typical school age in the first year.

We explore both the extensive margin of school enrollment during the 2007-8 school year and grade progression measures, as well as the intensive margin of school-related expenses. We find that a child with a one standard deviation higher ability test score has a $16 \%$ higher likelihood of being currently enrolled in school, while a child with a higher-ability sibling is $15 \%$ less likely to be currently enrolled and having two higher-ability siblings lowers a child's probability of enrollment by $30 \%$. Household fixed-effects regressions show that within a given household, a child with one standard deviation higher ability compared to the average ability of his or her siblings is $30 \%$ more likely to be enrolled. On the intensive margin, controlling for household fixed effects, we find that a child with one standard deviation higher ability receives $21 \%$ more discretionary school expenditures by the parents.

The remainder of the article is organized as follows. Section II discusses the conceptual framework about sibling rivalry and the household schooling investment decision. Section III describes the survey data used in the analysis and explains the construction of the different child ability measures. Section IV describes the empirical identification strategy, and Section $V$ presents the main results as well as robustness tests. Section VI presents conclusions.

\section{Sibling Rivalry Conceptual Framework}

Sibling rivalry represents the idea that within a household there is competition among siblings for limited resources. When market constraints (such as credit, capital, or labor) bind, all else equal, a child who has fewer siblings who are comparatively higher valued will be better off. Traditionally, the sibling rivalry literature for developing countries has focused on sibling sex composition and measuring the number of sisters that a given child has. The reason is that in cultures with a pro-male bias, investments in girls will generally have lower returns than investments in boys, and so having more sisters (i.e., siblings with lower returns) reduces competition for scarce resources and raises investments in all children. Sibling rivalry in child investments in poor countries is well documented (Parish and Willis [1993] for Taiwan, Binder [1998] for Mexico, Garg and Morduch [1998] for Ghana, Morduch [2000] for Tanzania, Edmonds [2007] for Nepal, Ota and Moffatt [2007] for India, and Dammert [2010] for Guatemala and Nicaragua). 
Although the empirical results from these studies are similar, the underlying behavioral models may differ. For instance, Garg and Morduch (1998) focus on credit constraints and differences in relative returns to investments in boys and girls as the cause for sibling rivalry. On the other hand, Edmonds (2007) and Dammert (2010) emphasize that when girls have comparative advantage in home production and it is not possible to hire labor for those tasks, both boys and girls will benefit from having more sisters, given the number of siblings, an outcome that is observationally indistinguishable from Garg and Morduch's (1998). In our study, by comparing direct measures of ability across siblings, our approach provides a test of sibling rivalry that does not depend on assumptions of gender bias in returns to education (Garg and Morduch 1998) or on division of labor based on gender (Edmonds 2007; Dammert 2010).

Most previous tests of sibling rivalry neglect that parents have additional knowledge about their children's capabilities and use this information to make school investment decisions. A literature embedded in testing the one-period consensus parental preferences model of human capital investment of Becker and Tomes (1976) and Behrman, Pollak, and Taubman (1982) uses child endowments in modeling the investment decision. ${ }^{2}$ Most studies that examine the investment decision process have to work around the fact that actual child ability or endowment is typically not observed (Behrman et al. 1982; Rosenzweig and Schultz 1982; Behrman, Rosenzweig, and Taubman 1994). Some recent studies are able to use direct measures of child ability. Kim (2005) uses an IQ test administered to Wisconsin high school juniors and finds that higher-ability children receive more parent transfers. Glick and Sahn (2010) use achievement test scores from Senegalese children taken in grade 2 to explain school outcomes 7 years later, but this neglects the role of siblings who may not have been enrolled in school.

In the study most closely related to ours, Ayalew (2005) uses Raven's CPM test scores for school-age children in one village in Ethiopia to measure child ability and, using a household fixed-effects model, finds that parents consider child ability when making school enrollment decisions. There are several key differences between our studies. First, we focus on absolute and relative direct measures of the ability of a child's siblings to generate inferences about the role of sibling rivalry in influencing schooling decisions. Second, we explore both alternative ability measures by using different cognitive tests and alternative outcomes such as school expenditures and grade progression, in addition to current enrollment, which is the focus of the Ayalew article. Third, we exploit

\footnotetext{
2 See Behrman (1997) for an overview of the consensus parental preferences models.
} 
the panel data structure as a robustness check to address potential reverse causality concerns about schooling influencing measures of child ability.

\section{Burkina Faso Social Protection Evaluation Survey}

The panel survey was conducted in June 2008 (year 1) and June 2009 (year 2) in Nahouri Province in southern Burkina Faso, located approximately 100 miles from the capital and bordering Ghana. Households were randomly selected from a village-level census conducted by our project team immediately prior to the round 1 survey in the 75 rural villages of Nahouri Province that each has a primary school. The survey is part of an ongoing project evaluating social protection strategies in Burkina Faso. Households in this region are predominantly subsistence farmers growing sorghum and groundnuts and have mean annual per capita expenditures of approximately $\$ 90$.

Our analysis focuses on primary school-aged children (5-15) in households with multiple biological children of the household head. There are 4,641 children in this age range in 1,507 different households. ${ }^{3}$ As shown in table 1, parental schooling is low, with only $13 \%$ of the children having a parent who ever attended school. In this children's sample, $54 \%$ are male, and the average age is 9.4 years. On average, these children have 3.8 siblings under age 15 , including 1.8 sisters. They live in households with an average of 8.9 individuals, including a head of household, 1.5 wives, 4.8 biological children of the household head under age 15, 0.4 children under age 15 who are not the biological children of the head, and 1.2 other members that include grandparents, aunts, uncles, and other extended family members.

Parents were directly asked about the chance of future success they believe each of their children will have in formal employment, a reasonable measure of parental perceptions about the investment return on their child's education, since most jobs in "formal employment" in Burkina Faso require a level of education beyond primary school and in particular French skills. This parental perception measure is based on everything the parent knows about the child and about the labor market, whether right or wrong, and was asked about every child in the household. For each child, the parents responded whether that particular child had a "small," "medium," "large," or "very large" chance of future success in formal employment. Parents considered $25 \%$ of these children to have a small chance of future success and only $8 \%$ to have a very

\footnotetext{
${ }^{3}$ All children in the regression sample are resident biological children of the household head. This means that there are no resident foster children included in the regressions. Furthermore, 3.9\% of all children are nonresident, and these children are excluded from the analysis as their ability was not measured.
} 
TABLE 1

SUMMARY STATISTICS OF BURKINA FASO SOCIAL PROTECTION EVALUATION DATA

\begin{tabular}{|c|c|c|c|}
\hline Variable & Mean & $\begin{array}{l}\text { Standard } \\
\text { Deviation }\end{array}$ & $\begin{array}{c}\text { Households } \\
\text { with Variation (\%) }\end{array}$ \\
\hline Household size & 8.88 & 3.81 & \\
\hline Number of wives & 1.46 & .95 & \\
\hline Number of siblings & 3.81 & 2.32 & \\
\hline Number of sisters & 1.79 & 1.50 & \\
\hline Number of nonbiological children in household & .41 & .89 & \\
\hline Male (fraction male) & .54 & .50 & \\
\hline Age & 9.41 & 2.99 & \\
\hline Birth order & 2.27 & 1.34 & \\
\hline Proportion either parent ever enrolled & .13 & .34 & \\
\hline Log household assets & 12.36 & 1.49 & \\
\hline \multicolumn{4}{|l|}{$\begin{array}{l}\text { Parent perception of chance child succeeds } \\
\text { in formal employment: }\end{array}$} \\
\hline Percentage small chance & 25 & & \\
\hline Percentage medium chance & 38 & & \\
\hline Percentage large chance & 29 & & \\
\hline Percentage very large chance & 8 & & \\
\hline Raven's raw test score & 4.86 & 3.35 & \\
\hline Own ability (Raven's age-adjusted z-score) & -.01 & 1.01 & \\
\hline WISC raw test score & 7.58 & 4.56 & \\
\hline WISC age-adjusted z-score & -.02 & .99 & \\
\hline Average grades completed & 1.81 & 2.08 & \\
\hline Proportion children currently enrolled & .54 & .50 & 56 \\
\hline Proportion children ever enrolled & .59 & .49 & 54 \\
\hline Proportion children with an on-time start & .40 & .49 & 55 \\
\hline Grade progression & .52 & .48 & \\
\hline Discretionary education expenditures (in FCFA) & 841 & 1,752 & \\
\hline Number of households & 1,507 & & \\
\hline Number of children & 4,641 & & \\
\hline
\end{tabular}

Source. Burkina Faso Social Protection Evaluation data from 2008.

Note. All summary statistics are based on information for the 4,641 children aged 5-15 in year 1 unless otherwise noted. Household assets are measured in FCFA (FCFA 415= US\$1), and the variable is created by taking the log of the sum of household durable goods and livestock. Parent perceptions of the chance their child succeeds in formal employment range from 0 to 3 , with 0 indicating a small chance and 3 indicating a very large chance. Own ability is measured using the Raven's CPM and normed by age (z-score). Timely start indicates if the child started school by age 7 or younger. Grade progression in school is the child's grade in school divided by the number of years since the child started attending school and ranges from 0 to 1. Discretionary education expenditures are the sum of per-child expenses for school supplies and parent association fees in FCFA. Summary statistics for grade progression are based on only 4,487 children because of missing data on the number of years since the child started attending school.

large chance of future success. Parents viewed most children $(67 \%)$ to have a medium $(38 \%)$ or large $(29 \%)$ chance of future success.

To corroborate these parent perceptions, we also examine externally validated measures about a child. We use the Raven's CPM and the WISC Digit Span to measure a child's cognitive ability; both tests do not require formal schooling to be able to answer the questions. The Raven's CPM is a measure of fluid intelligence or problem-solving ability. The test does not depend heavily 
on verbal skills, making it relatively "culture free" (Borghans et al. 2008). A child respondent is asked to select the image that is missing in order to complete a given picture (Raven, Raven, and Court 1998). This type of question is novel to the children in Nahouri Province, thus providing a more natural or true measure of problem-solving skills.

We ask 18 questions from the Raven's CPM, and on average, children in our sample answer 4.9 questions correctly. ${ }^{4}$ Younger children answer fewer questions correctly than older children (the average number correct for children age 5 is 2.8 and for children age 15 is 7.6). ${ }^{5}$ To control for this relationship between age and raw test scores, we calculate a $z$-score for each child measured as the child's raw test score minus the average score for the same-age children divided by the standard deviation of test scores for children of that age. ${ }^{6}$ Therefore, the mean of the Raven's $z$-score is zero and the standard deviation is one for each age and across all ages. ${ }^{7}$

The WISC Digit Span is a measure of working memory and ability to concentrate and has both a forward and a backward component. The respondent repeats a string of numbers to the enumerator and is scored by whether or not he or she repeats the full string correctly (Wechsler 1974). In the Digit Span Forward, the child must repeat the string of numbers exactly as stated by the enumerator. The string of numbers increases in length as the child answers correctly. With the Digit Span Backward, similar strings of numbers are to be repeated in the reverse order from that stated by the enumerator until the child can no longer continue. We calculate a total combined score of the forward and backward digit spans, and the children have an average score of 7.6 correct answers out of a total possible $32 .{ }^{8}$ As with the Raven, we calculate a WISC Digit Span age-adjusted $z$-score to control for age effects.

In table 1, we present summary statistics about children's schooling. Few households in rural Burkina Faso ever enroll all of their children. Only $54 \%$ of children are enrolled in the 2007-8 school year. Fifty-six percent of households experience variation in enrollment among their children aged 5-15, while 17\%

\footnotetext{
${ }^{4}$ During extensive pretesting of the Raven's test, results were consistent whether children were asked the entire set of 36 questions or only the odd-numbered questions. So to save interview time, we administered only the 18 odd-numbered questions (sets $\mathrm{A}, \mathrm{Ab}$, and $\mathrm{B}$ ).

5 The average number of questions answered correctly for children aged 6, 7, 8, 9, 10, 11, 12, 13, and 14 is, respectively, $2.8,3.6,4.4,5.1,5.3,5.6,6.1,6.5$, and 6.4.

${ }^{6}$ We did not use the international Raven's norming standards since we asked a subset of the Raven's test; what is most important here is how the children in rural Burkina Faso compare to each other, not internationally.

${ }^{7}$ Note that in Sec. V.B, we estimate alternative specifications to test the robustness of using the Raven's age-adjusted $z$-score instead of the raw test scores.

${ }^{8}$ Our regression results are robust to keeping the forward and backward digit span scores separate.
} 
enroll no children and only $27 \%$ of households currently enroll all of their primary school-aged children. If we consider whether a child has ever been enrolled in school rather than current enrollment during 2007-8, then 59\% of children in the sample have ever been enrolled and $54 \%$ of households experience variation across their children in whether a child has ever been enrolled. Given these low enrollment rates, on average these children have completed only 1.8 years of school.

In addition to examining the relationship between parent perceptions, child ability, and school enrollment, we explore three alternative schooling-related outcomes (on-time start, grade progression, and discretionary school expenses) in which sibling rivalry might matter. In Burkina Faso, parents typically enroll their children starting at age 7 , so we construct a variable to indicate if children started school by this age or if they were delayed. The "on-time start" variable shows that only $40 \%$ of primary school-aged children start school by age 7 , with the rest either starting at a later age or never attending school. Fifty-five percent of households have variation across their children in whether each child started school by age 7 . Second, we consider grade progression through school, which we calculate by dividing the child's highest grade attended by the number of years since the child started school. ${ }^{9}$ The grade progression measure ranges from zero to one, with higher numbers indicating quicker progress toward completing primary school. Third, for each child we calculate the total schooling-related discretionary expenditures during the 2007-8 school year. While school in Burkina Faso has relatively low registration fees (FCFA 904 on average per year, about $\$ 2.18$ using the June 2008 exchange rate of FCFA $415=$ US $\$ 1$ ), there are additional expenditures expected of each family when they enroll their child. These can include the purchase of uniforms, contributions for the school cafeteria, and transportation costs. Spreading resources evenly across children to pay the fixed costs associated with schooling may not be possible in the presence of liquidity constraints. However, for some of these expenditures, such as school supplies and parent association fees, parents have discretion in the amount spent each year on a child who is enrolled, and these discretionary expenditures are important in this setting as well as in developing countries that currently have free schooling. In our sample, the total average cost of sending a child to school is FCFA 3,867 per school year (about \$9.32), with parents spending, on average, FCFA 841 (about $\$ 2.04$ ) on these discretionary items per child (about $22 \%$ of total educational expenses).

\footnotetext{
${ }^{9}$ Children who never attended school are assigned a grade progression measure of zero.
} 


\section{Empirical Identification Strategy}

\section{A. Econometric Specification}

Studies of sibling rivalry in education typically use counts of the number of siblings and the number of sisters that a child has to explain different schooling outcomes (attendance, enrollment, attainment) as follows:

$$
e_{i b}=\omega_{0} S_{i b}+\omega_{1} F_{i h}+\alpha_{0} X_{i b}+\alpha_{1} Z_{h}+\varepsilon_{i h},
$$

where $e_{i b}$ is the educational outcome for child $i$ in household $h, S_{i b}$ is a count of the number of siblings the child has, $F_{i b}$ is a count of the number of female siblings the child has, $X_{i b}$ is a vector of individual characteristics such as age and gender that might influence parental investments, $Z_{h}$ is a vector of household characteristics, and $\varepsilon_{i h}$ is a random, idiosyncratic error term. The interpretation of $\omega_{0}$ is the change in $e_{i b}$ associated with an additional male sibling. The interpretation of $\omega_{1}$ is the change in $e_{i b}$ associated with the thought experiment of converting a sibling from a male to a female. The sum of $\omega_{0}+\omega_{1}$ is then the change in $e_{i b}$ associated with adding an additional female sibling. This approach takes current family size and composition as given at the time the parents make the enrollment decision.

To better understand parental schooling investment decisions, we expand on the sibling rivalry model in equation (1) to control for previously unobserved characteristics about the child (his ability) and his home environment (his siblings' ability) that might influence the parents' decision. We employ two empirical approaches to estimate this relationship. First, we estimate the following household or sibling fixed-effects conditional logit regression that will control for all household-level characteristics that are constant across siblings (Chamberlain 1980):

$$
e_{i h}=\beta_{0} A_{i h}+\alpha_{0} X_{i h}+\lambda_{b}+\eta_{i h},
$$

where $e_{i b}$ and $X_{i h}$ are defined as above, $A_{i h}$ is a direct measure of observed child ability, $\lambda_{b}$ is the household fixed effect that captures all characteristics about the household that are constant across siblings, and $\eta_{i b}$ is the child-specific idiosyncratic error term. In equation (1) and previous sibling rivalry papers, child ability was part of the error term, $\varepsilon_{i b}$, but in our analysis we are able to directly control for its effect on educational outcomes. ${ }^{10}$ This within-family estimate compares a child's own ability to the average ability of all the other children in

\footnotetext{
${ }^{10}$ Note that in the household fixed-effects specification, household characteristics, $Z_{h}$, and number of siblings, $S_{i h}$, will drop out of the specification because there is no variation across children within the household. In the household fixed-effects regressions, we also drop the variable for number of sisters, $F_{i h}$, because it is constant within a given household for children of the same gender.
} 
the household to examine if parents compare a child's ability to the average ability of his siblings when making human capital investment decisions.

While the household fixed-effects estimation compares own ability to average sibling ability, the second approach we adopt is to be more specific about the functional form of the sibling ability term and to include direct measures of sibling ability in the regression. This approach has the additional advantage that we can include the same variables as in the sibling rivalry literature (in eq. [1]) and allows us to examine how the relevant coefficients vary when also controlling for a child's own ability and his sibling's ability. We estimate the following extended equation (1) sibling rivalry regression:

$$
e_{i h}=\beta_{0} A_{i b}+\beta_{1} h\left(A_{-i b}\right)+\omega_{0} S_{i b}+\omega_{1} F_{i b}+\alpha_{0} X_{i b}+\alpha_{1} Z_{b}+\mu_{i b},
$$

where $h\left(A_{-i h}\right)$ is a measure of the ability of the other children $(-i)$ in household $h$ with varying functional forms that we discuss in detail below, and the other variables are as defined above. The error term, $\mu_{i b}$, measures the child-specific idiosyncratic part of $\varepsilon_{i b}$ not captured by a child's own ability, $A_{i b}$, or his sibling's ability, $h\left(A_{-i h}\right)$. The coefficients $\beta_{0}$ and $\beta_{1}$, respectively, give an estimate of the impact of child is own ability and his sibling's ability on child is enrollment.

We use several alternative measures of sibling ability, $h\left(A_{-i b}\right)$, including both absolute measures (highest sibling ability) and relative measures (whether there are any siblings with a higher ability score and dummies for the number of siblings with higher ability scores). Absolute measures provide insight into the role of the level of sibling ability in a household. Having siblings with high ability might represent competition for the child. However, if the high-ability siblings provide spillovers in learning to the child (such as tutoring) or if there are economies of scale in sending multiple children to school (such as sharing school supplies), then high-ability siblings could raise a child's own enrollment. It could be that the average level of sibling ability affects a child's enrollment differently than the ability level of the household's "best" sibling (with the highest ability). If sibling rivalry influences parents' deciding whom to send to school, then parents might consider how a child compares in ability to his siblings rather than considering the child's ability on its own, and relative sibling ability measures might be more informative. In our sample, $40 \%$ of the overall variation in ability arises from within-family variation across siblings, while $60 \%$ is between families.

\section{B. Potential Threats to Identification Strategy}

There are two main potential threats to our identification strategy. The first is that since schooling potentially affects cognitive ability, reverse causality is a possible problem we face. We attempt to address this in two ways. First, we 
estimate robustness specifications in which we limit the sample of children to grade 2 and lower or to grade 1 and lower. The decision to use this grade cutoff point is based on a regression of the Raven's age-adjusted $z$-score on grade in school, and the coefficients for grades 1 and 2 are close to zero (0.05 and 0.09, respectively) and not statistically significant. The coefficients for grades 3 and 4 are slightly larger ( 0.14 and 0.12 , respectively), but only the grade 3 coefficient is statistically significant whereas the grade 4 coefficient is not statistically significant. We interpret this lack of relationship between the lower grades and ability test scores as evidence that children in grade 2 and lower have not yet received enough schooling to influence their cognitive ability test scores. ${ }^{11} \mathrm{On}$ the basis of this information and to be conservative in our robustness specifications, we select grades 1 and 2 as the cutoff levels. Second, we restrict the sample to young children aged 5-7 (and 5-6) who are not enrolled in year 1 but for whom we have ability measures in year 1 and look at their enrollment in year 2. This eliminates any potential effect of schooling on the ability measures as these children were not enrolled at the time of taking the ability test.

The second potential threat to our identification strategy is that the Raven's test score is not just capturing the child's ability endowment but also reflects the complete history of all parental investments in the child, in particular, investments in early childhood nutrition, which are critical in this poor environment, and it is unlikely that these investments are randomly allocated among siblings. If parents are equity minded, they might compensate for unequal initial endowments among their children by providing more resources to those who have worse health. In this case, the current gap in observed ability between siblings will understate the actual ability difference, and this will bias

11 Our interpretation about the lack of relationship between the lower grades and ability involves the implicit assumption that either parents do not take into account child ability when they make schooling decisions or, if they do take ability into account, they always favor the more able children to attend school. If this assumption is violated so that the least able children are sent to school (because either parents take a compensating strategy or they act efficiently but the marginal rate of return to education is higher for the least able children), then we could observe no relationship between schooling and ability because the positive effects of schooling on ability are offset by the negative selection of low-ability children into school. While we do not think that parents' giving more schooling to their low-ability children is likely, this robustness check cannot completely rule out that possibility, so we offer two reasons supporting this assumption. First, Kazianga (2004) and Schultz (2004), using Burkina Faso nationally representative data, report substantial returns $(9 \%-16 \%)$ for an additional year of primary school, with returns to secondary $(14 \%-26 \%)$ and tertiary $(13 \%-23 \%)$ schooling even higher. Given that the rate of return to education is increasing in years of schooling, we conjecture that parents are more likely to enroll children who are perceived to be able to progress through the most grades. Second, in an environment in which private transfers among kin are common (Kazianga 2006), even if parents take a compensating strategy (over lifetime well-being), they could still choose to allocate more schooling to the most able of their children and expect that the well-off children will make transfers to the worse-off ones. 
the estimated effect of ability endowment downward. Alternatively, if parents are efficiency minded, they might provide more resources to their most robust children, in which case, the sibling ability gap is overstated and the estimated effect of ability endowment is biased upward. While we do not have the necessary data to fully address these biases, we can control for the nutritional and health investment history of the child by including the child's height for age $z$-score in the regression as an additional control variable. In these modified regressions, height for age $z$-scores have no significant effect on enrollment and they do not alter the relationship between ability and enrollment, providing some evidence that our results are not driven by parental investments in early childhood nutrition.

\section{Empirical Results}

\section{A. Sibling Rivalry, Parent Perceptions, and Child Ability}

Since we are building on the sibling rivalry literature, we begin our analysis estimating equation (1), which uses the standard observable family composition characteristics, number of siblings, number of sisters, and birth order. $^{12}$ Results of this regression are presented in table 2, column 1 . The number of sisters has a positive correlation with enrollment, consistent with sibling rivalry in the presence of promale bias in returns to school (Morduch 2000). As discussed in Section II, a typical explanation for sibling rivalry is that rivalry is driven by constraints inducing parents to invest in human capital on the basis of differences in expected returns to investment in their offspring. In settings in which the expected returns are higher for boys than for girls, having more girls (low-return children) lowers competition over resources and raises investments in all children. With the number of sisters held constant, the addition of a male sibling is correlated with a 2.5 percentage point (or $4.6 \%$ ) lower likelihood of attending school. Switching from a male to a female sibling is correlated with a 2.2 percentage point higher likelihood of enrollment, or $4.1 \%$ of the base enrollment. Birth order has a positive coefficient, indicating that younger siblings are more likely to be enrolled, as is consistent with the literature in developing countries. Children with better-educated or wealthier parents are more likely to be enrolled, which is consistent with intergenerational education transmission and wealth effects.

As discussed in Section IV.A, other factors about the child besides these observable demographic characteristics are likely to influence the parents' schooling investment decision. Parents know more about their children's

12 These counts of the number of siblings and number of sisters include both resident and nonresident children. Results are robust to restricting these variables to measure only the number of resident siblings and sisters. 
TABLE 2

MARGINAL EFFECTS FROM LOGIT AND CONDITIONAL LOGIT REGRESSIONS ESTIMATING RELATIONSHIP BETWEEN CURRENT SCHOOL ENROLLMENT, SIBLING RIVALRY, AND PARENT PERCEPTIONS

\begin{tabular}{|c|c|c|c|c|c|}
\hline & \multicolumn{5}{|c|}{ Dependent Variable: Current Enrollment } \\
\hline & (1) & (2) & (3) & (4) & (5) \\
\hline \multicolumn{6}{|l|}{ Parent perceptions of child's chance of success } \\
\hline in formal employment & & $\begin{array}{l}.184^{\star \star \star} \\
{[.025]}\end{array}$ & $\begin{array}{l}.162^{\star \star \star} \\
{[.023]}\end{array}$ & $\begin{array}{l}.111^{\star \star \star} \\
{[.019]}\end{array}$ & $\begin{array}{l}.109^{\star \star \star} \\
{[.019]}\end{array}$ \\
\hline Highest sibling perception & & & $\begin{array}{l}-.065^{\star \star \star} \\
{[.019]}\end{array}$ & & \\
\hline \multicolumn{6}{|l|}{ Higher sibling dummy ( 1 if any sibling with a } \\
\hline higher perceived chance of success) & & & & $\begin{array}{c}-.070^{\star \star} \\
{[.033]}\end{array}$ & \\
\hline \multirow{2}{*}{$\begin{array}{l}\text { One higher sibling dummy ( } 1 \text { if only one sibling } \\
\text { with a higher perceived chance of success) }\end{array}$} & & & & & \\
\hline & & & & & $\begin{array}{l}-.053 \\
{[.035]}\end{array}$ \\
\hline \multirow{2}{*}{$\begin{array}{l}\text { Two higher sibling dummy ( } 1 \text { if two siblings with } \\
\text { a higher perceived chance of success) }\end{array}$} & & & & & \\
\hline & & & & & $\begin{array}{l}-.076 \\
{[.048]}\end{array}$ \\
\hline \multirow{2}{*}{$\begin{array}{l}\text { Three or more higher sibling dummy ( } 1 \text { if three or } \\
\text { more siblings with a higher perceived chance } \\
\text { of success) }\end{array}$} & & & & & \\
\hline & & & & & $\begin{array}{c}-.146^{\star \star} \\
{[.063]}\end{array}$ \\
\hline \multirow[t]{2}{*}{ Number of siblings } & $-.025^{\star \star \star}$ & & $-.025^{\star \star \star}$ & $-.027^{\star \star \star}$ & $-.026^{\star \star \star}$ \\
\hline & [.009] & & {$[.009]$} & {$[.009]$} & {$[.009]$} \\
\hline Number of sisters & $\begin{array}{l}.022^{\star \star} \\
{[.010]}\end{array}$ & & $\begin{array}{l}.021^{\text {*x }} \\
{[.010]}\end{array}$ & $\begin{array}{l}.022^{\text {*x }} \\
{[.010]}\end{array}$ & $\begin{array}{l}.022^{\text {*ᄎ }} \\
{[.010]}\end{array}$ \\
\hline \multirow[t]{2}{*}{ Birth order } & $.016^{\star}$ & & $.027^{\star \star \star}$ & $.025^{\star \star}$ & $.027^{\star \star \star}$ \\
\hline & {$[.009]$} & & {$[.010]$} & {$[.010]$} & {$[.010]$} \\
\hline \multirow[t]{2}{*}{ Male } & $.033^{\star}$ & $.041^{\star \star}$ & .028 & .029 & .029 \\
\hline & {$[.019]$} & {$[.019]$} & {$[.019]$} & {$[.019]$} & {$[.019]$} \\
\hline \multirow[t]{2}{*}{ Parent schooling (either parent ever enrolled $=1$ ) } & $.180^{\star \star \star}$ & & $.169^{\star \star \star}$ & $.164^{\star \star \star}$ & $.165^{\star \star \star}$ \\
\hline & {$[.040]$} & & {$[.044]$} & {$[.044]$} & {$[.044]$} \\
\hline \multirow[t]{2}{*}{ Log household assets } & $.018^{*}$ & & $.017^{\star}$ & .017 & .017 \\
\hline & {$[.010]$} & & {$[.010]$} & {$[.010]$} & {$[.010]$} \\
\hline Age fixed effects? & Yes & Yes & Yes & Yes & Yes \\
\hline Village fixed effects? & Yes & No & Yes & Yes & Yes \\
\hline Household fixed effects? & No & Yes & No & No & No \\
\hline Number of children & 4,641 & 3,211 & 4,538 & 4,538 & 4,538 \\
\hline
\end{tabular}

Source. Burkina Faso Social Protection Evaluation data from 2008.

Note. Robust standard errors are in brackets, clustered at the village level. Columns 1, 3, 4, and 5 present marginal effects for logit regressions. Column 2 presents marginal effects from a household fixed-effects conditional logit regression. Regressions are restricted to children aged 5-15, and number of siblings and number of sisters are for all siblings and sisters in the household. Regression sample includes 4,641 children, of which 4,538 have parent perception measures and 3,211 have siblings with differing outcomes and parent perception measures.

* Significant at $10 \%$.

** Significant at $5 \%$.

$\star \star \star$ Significant at $1 \%$.

This content downloaded from 139.078.028.086 on March 19, 2019 14:34:52 PM

All use subject to University of Chicago Press Terms and Conditions (http://www.journals.uchicago.edu/t-and-c). 
characteristics than simply their gender and sibling composition. Since it is the parents' perceptions of their child's ability or potential for future success, whether correct or not, that inform and affect their decision about educational investment, we first examine the relationship between school enrollment and these parents' perceptions about each of their children. ${ }^{13}$ We estimate both a household fixed-effects conditional logit model as in equation (2) and an extended sibling rivalry logit regression as in equation (3), and in columns 2-5 of table 2 we present the corresponding results. ${ }^{14}$ We find a positive relationship between what parents think about a child and his current enrollment. On the other hand, perceptions of the child's siblings in the same age group have a negative relationship with the child's enrollment, suggesting that parents make educational investment decisions on the basis of not only what they think of one child but also what they think of that child's siblings.

The household fixed-effects specification in table 2, column 2, shows that children with one level higher parental perceptions compared to the average perceptions of their siblings have an 18.4 percentage point higher probability of enrollment, which corresponds to a $34.1 \%$ higher enrollment level. In columns 3-5, we explicitly estimate the relationship between parent perceptions about the child's siblings and a child's enrollment. When we control for direct measures of parent perceptions of siblings, parental perceptions of the child are still positively correlated with the child's enrollment. One level higher parent perceptions is correlated with a 10.9-16.2 percentage point higher likelihood of enrollment. However, parental perceptions of a child's siblings are negatively correlated with the child's enrollment. Compared to the household fixed-effects specification in which the parental perceptions of the child are compared to the average of his siblings, an alternative is to make the comparison with the parental perceptions of the "best" sibling. Results in column 3 show that children whose sibling with the highest perception in the family has a one level higher value have a 6.5 percentage point lower likelihood of enrollment.

Relative sibling perceptions might be more relevant than absolute sibling perceptions since having a sibling whom the parents think of more highly than

\footnotetext{
13 The parent perception variable takes values of $0-3$, where 0 means a child has a small chance of future success, 1 a medium chance, 2 a large chance, and 3 a very large chance. Parents on average report that their children have a medium chance of success, with the variable having a mean of 1.2 and a standard deviation of 0.9 . In the survey, we also record the identity of the person reporting the perception (father, mother, or other adult family member). For $80.5 \%$ of the children, the father reports his perceptions, while for $13.5 \%$ of the children, the mother reports her perceptions. The remaining $6 \%$ of children have perceptions reported by another adult family member. Results are robust to estimating the table 2 regressions using only perceptions of the father, using only perceptions of the mother, or excluding the children whose perceptions were not reported by the biological parents. 14 Parent perceptions may be influenced by the child's enrollment status, and therefore, the results presented in this table should not necessarily be interpreted as causal.
} 
oneself could matter more than the overall perception level of one's siblings. Column 4 uses an indicator if the child has any sibling with higher parental perceptions, while column 5 uses indicators for whether the child has one, two, or three or more siblings with higher parental perceptions. Children having a sibling with higher parent perceptions have a 7.0 percentage point lower probability of enrollment. Children with three or more siblings with higher parental perceptions have a 14.6 percentage point lower probability of being enrolled.

While parental perceptions about their child's chance of future success are correlated with the child's current school enrollment, these perceptions may or may not be accurate or well informed. There may be significant differences across households in how parents perceive their own children and what factors they take into account in formulating perceptions. Nevertheless, it is likely that parents' decisions are related to their perceptions, and so analyzing these perceptions provides useful insights and takes advantage of a unique variable in the data set that we can then corroborate with more "objective" measures of ability. We incorporate an externally validated measure of the child's cognitive ability using the Raven's CPM test. These tests were administered during the baseline survey to every child aged 5-15 regardless of his or her current enrollment status and provide a consistent measure of child ability across children in all households. There is a strong positive relationship between the ability measure and parent perceptions. Higher-ability children are viewed by their parents as having a higher chance of future success. However, after we control for gender and age, the ability measure explains only about $20 \%$ of the variation in parental perceptions.

In table 3, we estimate the relationship between child ability (as measured by the Raven's age adjusted $z$-score) and current school enrollment using a household fixed-effects conditional logit as described in equation (2) and a logit regression with alternative sibling ability measures as described in equation (3). ${ }^{15}$ The household fixed-effects logit results in column 1 indicate that a child with one standard deviation higher own ability compared to the average of his siblings has a 16.4 percentage point higher likelihood of being currently enrolled, corresponding to $30.4 \%$ of the base enrollment. The coefficient is significant at the $1 \%$ level. This is evidence that parents take into account a child's cognitive ability in deciding enrollment, and the magnitude of the effect is large.

When considering how parents decide on enrollment, one approach would be for them to compare a child's ability with his siblings' average ability, and

15 All regressions include child gender and age dummies, and the regressions estimating eq. (3) also
include village fixed effects, parent schooling, household assets, and family demographic composition
measures. Results presented in table 3 are consistent when using the number of siblings and the
number of sisters aged $5-15$ rather than the number of siblings and sisters aged $0-15$. Correlation
among the error terms of children in a given village experiencing the same enrollment environment
might bias the standard errors downward, so in all regressions we cluster the standard errors by village. 
TABLE 3

MARGINAL EFFECTS FROM LOGIT AND CONDITIONAL LOGIT REGRESSIONS ESTIMATING RELATIONSHIP BETWEEN CURRENT SCHOOL ENROLLMENT AND CHILD ABILITY

\begin{tabular}{|c|c|c|c|c|}
\hline & \multicolumn{4}{|c|}{ Dependent Variable: Current Enrollment } \\
\hline & (1) & $(2)$ & (3) & (4) \\
\hline Own ability (Raven's age-adjusted z-score) & $\begin{array}{l}.164^{\star \star \star} \\
{[.017]}\end{array}$ & $\begin{array}{l}.147^{\star \star \star} \\
{[.014]}\end{array}$ & $\begin{array}{l}.096 * \star \star \\
{[.016]}\end{array}$ & $\begin{array}{l}.086 * \star \star \\
{[.016]}\end{array}$ \\
\hline Highest sibling ability & & $\begin{array}{l}-.067^{\star \star \star} \\
{[.013]}\end{array}$ & & \\
\hline $\begin{array}{l}\text { Higher sibling dummy ( } 1 \text { if any sibling with } \\
\text { an ability > own ability) }\end{array}$ & & & $\begin{array}{l}-.106^{\star \star \star *} \\
{[.023]}\end{array}$ & \\
\hline $\begin{array}{l}\text { One higher sibling dummy ( } 1 \text { if only one } \\
\text { sibling with an ability > own ability) }\end{array}$ & & & & $\begin{array}{l}-.082^{\star \star \star} \\
{[.024]}\end{array}$ \\
\hline $\begin{array}{l}\text { Two higher sibling dummy ( } 1 \text { if two siblings } \\
\text { with an ability > own ability) }\end{array}$ & & & & $\begin{array}{l}-.161^{\star \star *} \\
{[.031]}\end{array}$ \\
\hline $\begin{array}{l}\text { Three or more higher sibling dummy ( } 1 \text { if } \\
\text { three or more siblings with an ability } \\
>\text { own ability) }\end{array}$ & & & & $\begin{array}{l}-.172^{\star \star \star} \\
{[.042]}\end{array}$ \\
\hline Number of siblings & & $\begin{array}{l}-.020^{\star \star} \\
{[.009]}\end{array}$ & $\begin{array}{l}-.024^{\star \star \star} \\
{[.009]}\end{array}$ & $\begin{array}{l}-.018^{\star \star} \\
{[.009]}\end{array}$ \\
\hline Number of sisters & & $\begin{array}{r}.018^{*} \\
{[.010]}\end{array}$ & $\begin{array}{l}.020^{\star \star} \\
{[.010]}\end{array}$ & $\begin{array}{r}.019^{*} \\
{[.010]}\end{array}$ \\
\hline Birth order & & $\begin{array}{l}.029^{\star \star \star} \\
{[.010]}\end{array}$ & $\begin{array}{l}.026^{\star \star \star} \\
{[.009]}\end{array}$ & $\begin{array}{l}.031^{\star \star \star} \\
{[.010]}\end{array}$ \\
\hline Male & $\begin{array}{c}.027 \\
{[.020]}\end{array}$ & $\begin{array}{c}.020 \\
{[.020]}\end{array}$ & $\begin{array}{c}.021 \\
{[.020]}\end{array}$ & $\begin{array}{c}.020 \\
{[.020]}\end{array}$ \\
\hline $\begin{array}{l}\text { Parent schooling (either parent ever } \\
\text { enrolled }=1 \text { ) }\end{array}$ & & $\begin{array}{l}.180 \star \star \star \\
{[.041]}\end{array}$ & $\begin{array}{l}.179 * \star \star \\
{[.041]}\end{array}$ & $\begin{array}{l}.179 * \star \star \\
{[.041]}\end{array}$ \\
\hline Log household assets & & $\begin{array}{r}.018^{*} \\
{[.010]}\end{array}$ & $\begin{array}{c}.019^{*} \\
{[.010]}\end{array}$ & $\begin{array}{c}.019^{*} \\
{[.010]}\end{array}$ \\
\hline Age fixed effects? & Yes & Yes & Yes & Yes \\
\hline Village fixed effects? & No & Yes & Yes & Yes \\
\hline Household fixed effects? & Yes & No & No & No \\
\hline Number of children & 2,862 & 4,641 & 4,641 & 4,641 \\
\hline
\end{tabular}

Source. Burkina Faso Social Protection Evaluation data from 2008

Note. Robust standard errors are in brackets, clustered at the village level. Column 1 presents marginal effects from a household fixed-effects conditional logit regression. Columns 2-4 present marginal effects for logit regressions. Regressions are restricted to children aged 5-15, and number of siblings and number of sisters are for all siblings and sisters in the household. Regression sample includes 4,641 children, with 2,862 having siblings with differing enrollment outcomes. Own and sibling ability are measured using the Raven's CPM and normed by age (z-score).

* Significant at $10 \%$.

** Significant at $5 \%$.

$\star \star \star$ Significant at $1 \%$.

This content downloaded from 139.078.028.086 on March 19, 2019 14:34:52 PM

All use subject to University of Chicago Press Terms and Conditions (http://www.journals.uchicago.edu/t-and-c). 
this is captured in the household fixed-effects specification. An alternative that takes into account the nonlinear relationship between siblings' abilities would consider the impact of the sibling with the highest ability. Another approach would include relative measures indicating if the child has any sibling with a higher ability measure or whether the child has one, two, or three or more siblings with higher ability measures. ${ }^{16}$ When we control for these direct measures of sibling ability (in cols. 2-4), the child's own ability is still positively correlated with his enrollment and statistically significant at the $1 \%$ level. One standard deviation higher own ability is correlated with a $15.9 \%-27.2 \%$ higher likelihood of enrollment compared to the base enrollment level. Having one's "best" sibling have a one standard deviation higher ability is correlated with a 6.7 percentage point lower enrollment rate (col. 2). Likewise, having any sibling with a higher ability is correlated with a 10.6 percentage point lower likelihood of being enrolled (col. 3), and this effect is magnified if there are two siblings with higher abilities (16.1 percentage points). These coefficients are all significant at the $1 \%$ level. ${ }^{17}$

Including child ability and sibling ability measures does not significantly alter the family demographic composition variables. The sign and level of statistical significance are consistent with the initial regression presented in table 2, column 1, while the magnitude of the coefficient for the number of siblings and number of sisters is somewhat reduced. Overall, these sibling ability rivalry results are consistent with the parental perceptions regressions in table 2 and indicate that part of what is driving the relationship between parental perceptions and the school enrollment decision is the child's ability. ${ }^{18}$

16 Results are robust to additional sibling ability measures including median sibling ability, the number of siblings with a higher ability, dummies for whether a child's ability is highest or lowest in the household, and whether the child has any siblings who have ability measures one-half or one standard deviation higher.

17 School investments potentially involve dynamic effects such as state dependence once a child is enrolled, and this could mean that younger and older children face different constraints; therefore, different sibling rivalries are relevant for their enrollment decision. To address this issue that the regressions combine young and old children and treat the relationship between ability and enrollment symmetrically for all children, we estimate a series of regressions (results not shown) in which we split the sample of children into younger (ages 5-9) and older (ages 10-15) children, as well as split the sibling ability measures into variables for younger and older siblings. For young children, having a higher-ability young sibling in the same age range has a significant negative impact on own enrollment, but there is no relationship between older sibling ability and enrollment. This result that young children are competing with other young siblings for school investments contrasts with that for older children, who appear to be competing with both younger and older siblings.

18 We also explore whether the relationship between child ability and enrollment is altered by the gender of the child, household wealth, or parental schooling by including interactions of these variables with the ability measure. While sibling rivalry appears to be more important for girls than 
Having explored the relationship between child ability and the extensive margin of school enrollment, we next turn to the intensive margin of educational expenditures. This allows us to rule out the interpretation that the results presented in tables 2 and 3 reflect solely the desire of the child to attend school. If a higher-ability child intrinsically has more motivation for attending school, that could potentially explain the table 3 results showing a relationship between ability and enrollment. However, a child with more desire to attend school would not explain the table 4 results that show a relationship between child ability and parents' discretionary education expenditures. We focus on expenses for school supplies and parent association voluntary fees because these have a discretionary component, whereby parents have some leeway in how much they spend on each of their children. ${ }^{19}$ For the regressions presented in table 4, we restrict the sample of 4,641 children aged 5-15 living in households with multiple siblings to only the 2,514 children who are currently enrolled in school. We estimate a series of regressions similar to those in table 3 (household fixed effects in col. 1 and then alternative sibling ability measures in cols. 2-4). Results in column 1 indicate that within a given household, children with a one standard deviation higher ability receive FCFA 174 more in discretionary expenditures, representing $20.7 \%$ of mean discretionary expenses, and the coefficient is significant at the $1 \%$ level. Controlling directly for alternative functional forms of sibling ability in columns $2-4$ does not alter the positive relationship between a child's own ability and educational expenses, with coefficients ranging from FCFA 114 to FCFA 142. Finally, children with two siblings of higher ability have FCFA 140 lower educational expenditures, corresponding to $16.6 \%$ of discretionary educational expenses.

\section{B. Robustness Checks}

To test the robustness of our results, we present four tables of regressions in which we explore different educational outcomes, use two approaches to address potential reverse causality issues between schooling and cognitive ability, and use alternative cognitive tests to measure child ability. First, in table 5, we present results for alternative schooling outcomes including ever enrolled in

for boys, we cannot reject the equality of coefficients between the genders. Likewise, while the estimates for poor families (defined as households with log assets below the mean, below the median, or in the bottom quintile) are larger, we cannot reject that poor and nonpoor families have the same level of sibling rivalry. Finally, we cannot reject that children of educated and uneducated parents have the same levels of sibling rivalry.

${ }_{19}$ School registration fees are not considered since all enrolled children have to pay the same fees. School meal fees, lodging fees, uniforms, and transportation expenses are the other educational expenses that are not included as these have much less variation across siblings within a household. 
TABLE 4

ORDINARY LEAST SOUARES REGRESSIONS ESTIMATING RELATIONSHIP BETWEEN DISCRETIONARY EDUCATION EXPENDITURES AND CHILD ABILITY, ONLY ENROLLED CHILDREN

\begin{tabular}{|c|c|c|c|c|}
\hline & \multicolumn{4}{|c|}{$\begin{array}{c}\text { Dependent Variable: Discretionary Education } \\
\text { Expenditures on Supplies and Parent } \\
\text { Associations Fees (FCFA) }\end{array}$} \\
\hline & (1) & (2) & (3) & (4) \\
\hline Own ability (Raven's age-adjusted z-score) & $\begin{array}{l}174.40^{\star \star \star} \\
{[53.78]}\end{array}$ & $\begin{array}{l}142.48^{\star \star} \\
{[54.99]}\end{array}$ & $\begin{array}{r}125.64^{*} \\
{[69.82]}\end{array}$ & $\begin{array}{l}114.13 \\
{[75.09]}\end{array}$ \\
\hline Highest sibling ability & & $\begin{array}{c}-38.49 \\
{[40.41]}\end{array}$ & & \\
\hline $\begin{array}{l}\text { Higher sibling dummy ( } 1 \text { if any sibling in household } \\
\text { with an ability > own ability) }\end{array}$ & & & $\begin{array}{l}-10.66 \\
{[66.09]}\end{array}$ & \\
\hline $\begin{array}{l}\text { One higher sibling ability dummy ( } 1 \text { if only one } \\
\text { sibling in household with an ability > own ability) }\end{array}$ & & & & $\begin{array}{c}27.98 \\
{[71.62]}\end{array}$ \\
\hline $\begin{array}{l}\text { Two higher sibling ability dummy ( } 1 \text { if two } \\
\text { siblings in household with an ability }> \\
\text { own ability) }\end{array}$ & & & & $\begin{array}{c}-139.67^{\star} \\
{[76.49]}\end{array}$ \\
\hline $\begin{array}{l}\text { Three or more higher sibling ability dummy } \\
\text { ( } 1 \text { if three or more siblings in household } \\
\text { with an ability }>\text { own ability) }\end{array}$ & & & & $\begin{array}{c}-50.46 \\
{[139.60]}\end{array}$ \\
\hline Number of siblings & & $\begin{array}{l}25.65 \\
{[34.31]}\end{array}$ & $\begin{array}{c}22.24 \\
{[33.48]}\end{array}$ & $\begin{array}{c}26.11 \\
{[35.31]}\end{array}$ \\
\hline Number of sisters & & $\begin{array}{r}-68.59^{*} \\
{[40.04]}\end{array}$ & $\begin{array}{r}-67.28^{*} \\
{[39.95]}\end{array}$ & $\begin{array}{c}-68.50^{*} \\
{[40.21]}\end{array}$ \\
\hline Birth order & & $\begin{array}{l}-17.31 \\
{[38.79]}\end{array}$ & $\begin{array}{l}-22.02 \\
{[39.76]}\end{array}$ & $\begin{array}{l}-14.01 \\
{[37.67]}\end{array}$ \\
\hline Male & $\begin{array}{l}-80.95 \\
{[84.80]}\end{array}$ & $\begin{array}{l}-63.54 \\
{[67.69]}\end{array}$ & $\begin{array}{l}-62.85 \\
{[68.29]}\end{array}$ & $\begin{array}{l}-62.57 \\
{[68.06]}\end{array}$ \\
\hline $\begin{array}{l}\text { Parent schooling (either parent ever } \\
\quad \text { enrolled }=1 \text { ) }\end{array}$ & & $\begin{array}{l}256.03^{\star \star} \\
{[116.42]}\end{array}$ & $\begin{array}{l}254.71^{\star \star} \\
{[116.75]}\end{array}$ & $\begin{array}{l}253.51^{\star \star} \\
{[116.98]}\end{array}$ \\
\hline Log household assets & & $\begin{array}{c}12.14 \\
{[25.79]}\end{array}$ & $\begin{array}{c}11.68 \\
{[25.56]}\end{array}$ & $\begin{array}{c}12.27 \\
{[25.91]}\end{array}$ \\
\hline Age fixed effects? & Yes & Yes & Yes & Yes \\
\hline Village fixed effects? & No & Yes & Yes & Yes \\
\hline Household fixed effects? & Yes & No & No & No \\
\hline Number of children & 1,999 & 2,514 & 2,514 & 2,514 \\
\hline
\end{tabular}

Source. Burkina Faso Social Protection Evaluation data from 2008.

Note. Robust standard errors in are brackets, clustered at the village level. All regressions are restricted to children aged 5-15 who are currently enrolled in school. Discretionary education expenditures are the sum of per-child expenses for school supplies and other parent association fees in FCFA, with a mean of FCFA 841. The regression in col. 1 includes household fixed effects, and the sample is restricted to children in households with at least two enrolled children. Columns 2-4 include village fixed effects, and the sample is restricted to children who are currently enrolled. Own and sibling ability are measured using the Raven's CPM and normed by age (z-score).

* Significant at $10 \%$.

** Significant at $5 \%$.

*** Significant at $1 \%$.

This content downloaded from 139.078.028.086 on March 19, 2019 14:34:52 PM

All use subject to University of Chicago Press Terms and Conditions (http://www.journals.uchicago.edu/t-and-c). 
TABLE 5

MARGINAL EFFECTS FROM LOGIT AND CONDITIONAL LOGIT REGRESSIONS ESTIMATING RELATIONSHIP BETWEEN ALTERNATIVE SCHOOLING OUTCOMES AND CHILD ABILITY

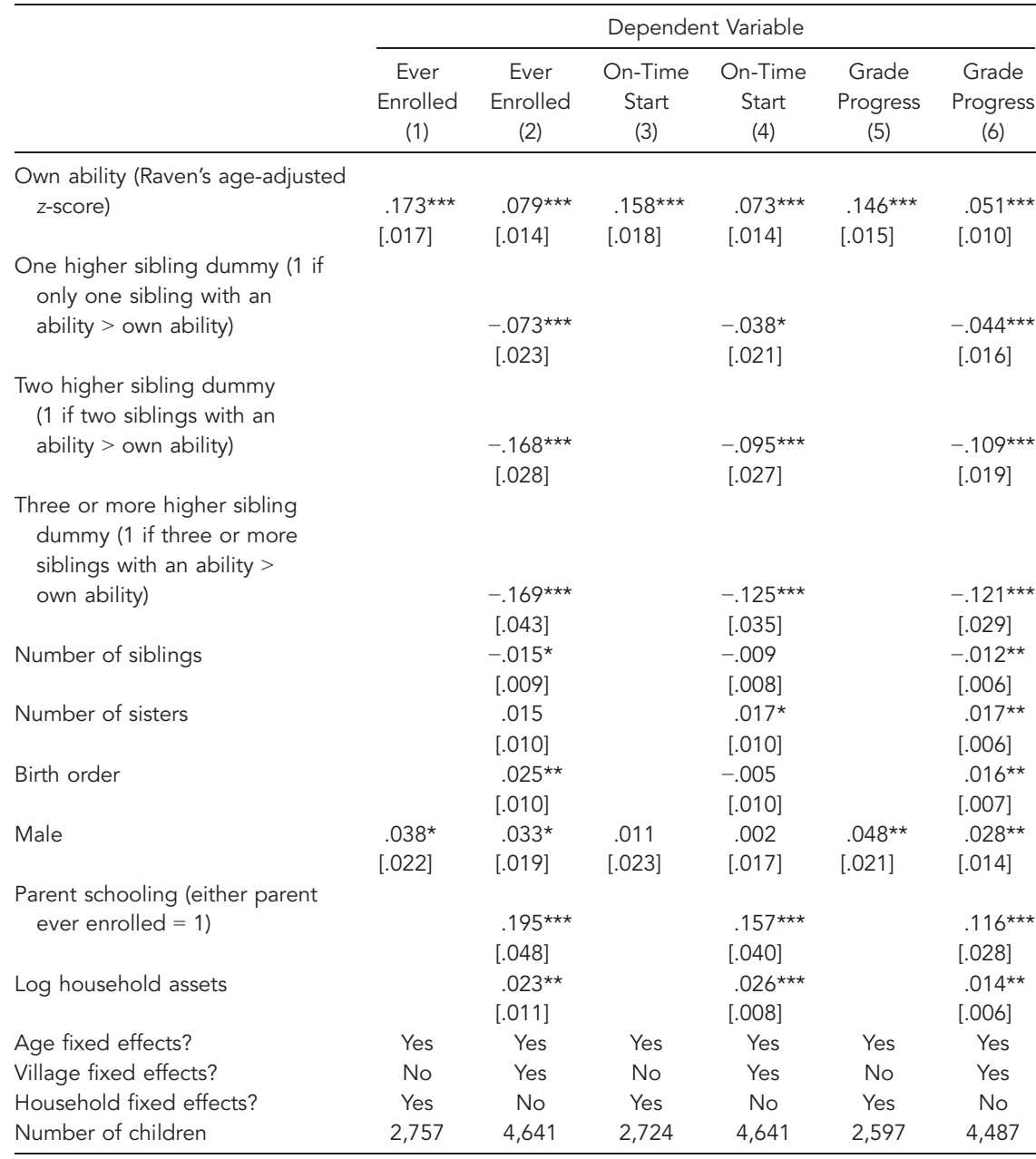

Source. Burkina Faso Social Protection Evaluation data from 2008.

Note. Robust standard errors are in brackets, clustered at the village level. Columns 1 and 3 present marginal effects for a household fixed-effects conditional logit regression. Columns 2 and 4 present marginal effects for logit regressions. Column 5 uses ordinary least squares and includes household fixed effects, while col. 6 includes village fixed effects. Regressions are restricted to children aged 5-15. On-time start indicates if the child started school by age 7 or younger, and grade progression is the child's grade in school divided by the number of years since the child started school and ranges from 0 to 1 . Own and sibling ability are measured using the Raven's CPM and normed by age. Regression sample includes 4,641 children who also have siblings in their household. Owing to missing data on the number of years since the child started school, the sample size in col. 6 is only 4,487

* Significant at $10 \%$.

** Significant at $5 \%$.

$\star \star \star$ Significant at $1 \%$.

This content downloaded from 139.078.028.086 on March 19, 2019 14:34:52 PM

All use subject to University of Chicago Press Terms and Conditions (http://www.journals.uchicago.edu/t-and-c). 
school, on-time school start, and grade progression through school. Results are consistent with those in table 3 for current enrollment. We use household fixed effects as well as the relative measure of whether a child has one, two, or three or more siblings of higher ability. ${ }^{20}$ Relative to the base levels, in the household fixed-effects specifications (cols. 1, 3, and 5), children with one standard deviation higher own ability are $29 \%$ more likely to be ever enrolled, $40 \%$ more likely to start school on time, and $28 \%$ more likely to progress through school. Children with one sibling of higher ability have a lower probability of these outcomes (12\% lower level of ever being enrolled, $10 \%$ lower level of starting school on time, and $8 \%$ lower level of grade progression). Negative effects are larger for children who have two siblings of higher ability (28\% lower level of ever being enrolled, $24 \%$ lower level of starting school on time, and $21 \%$ lower level of grade progression).

Second, in table 6, we attempt to address the potential reverse causality of schooling affecting a child's cognitive ability by limiting the regression sample to children who are in grade 2 or grade 1 or not enrolled (cols. 1-4) and children in grade 1 or not enrolled (cols. 5-8) because the regression evidence discussed previously indicates that children in these grades have not yet received enough schooling to influence their cognitive ability test scores. Results for this restricted sample are consistent with those in table 3. Household fixed-effects logit regressions in columns 1 and 5 indicate that within a given household, relative to the base enrollment levels, a child with one standard deviation higher ability is, respectively, $32 \%$ and $34 \%$ more likely to be enrolled. ${ }^{21}$ Children with two siblings of higher ability have a 6.1 or 3.9 percentage point lower probability of enrollment (cols. 4 and 8, respectively), corresponding to $17.4 \%$ and $17.0 \%$ of the base level of enrollment.

Third, in table 7 , we further address any potential reverse causality between schooling and cognitive ability by using the ability measure of young children who are not enrolled in 2007-8 to measure the effect on schooling in 2008-9. This approach eliminates any potential effect of schooling on the ability measure as these children had never been enrolled at the time of taking the ability test, so the comparison is for the children not enrolled in year 1 to their siblings who are not enrolled. In columns 1-4, we first consider only children aged 5-7 and not enrolled in year 1 since many children in Burkina Faso are not enrolled at this young age. Then in columns $5-8$, we further restrict the sample to only children

\footnotetext{
20 We also estimate regressions including the highest sibling ability and whether the child has any sibling of higher ability and find consistent results; but because of space limitations, we present the limited set of results.

21 Mean enrollment for the sample of children in grade 2 or grade 1 or not enrolled (cols. 1-4) is 0.35 , while for children in grade 1 or not enrolled (cols. 5-8), average enrollment is 0.23.
} 


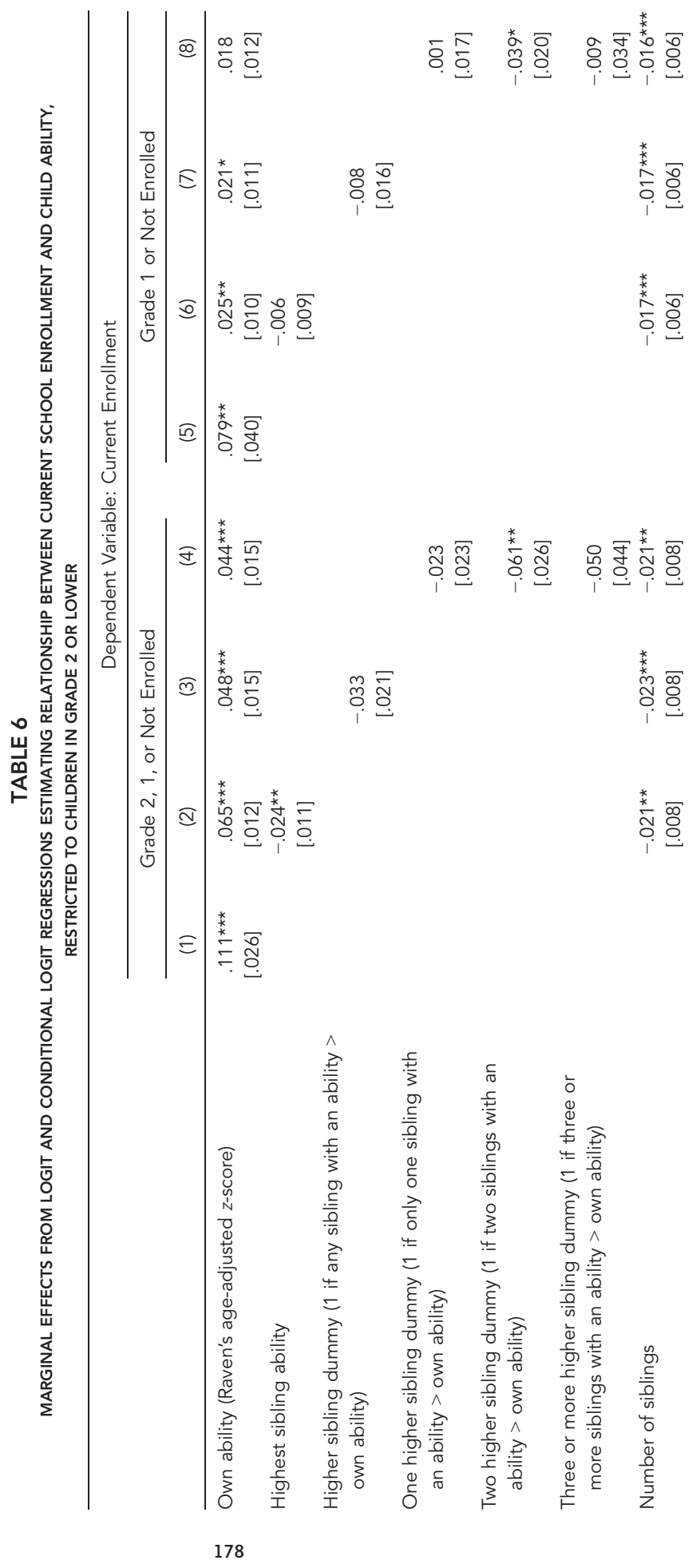

This content downloaded from 139.078.028.086 on March 19, 2019 14:34:52 PM All use subject to University of Chicago Press Terms and Conditions (http://www.journals.uchicago.edu/t-and-c). 


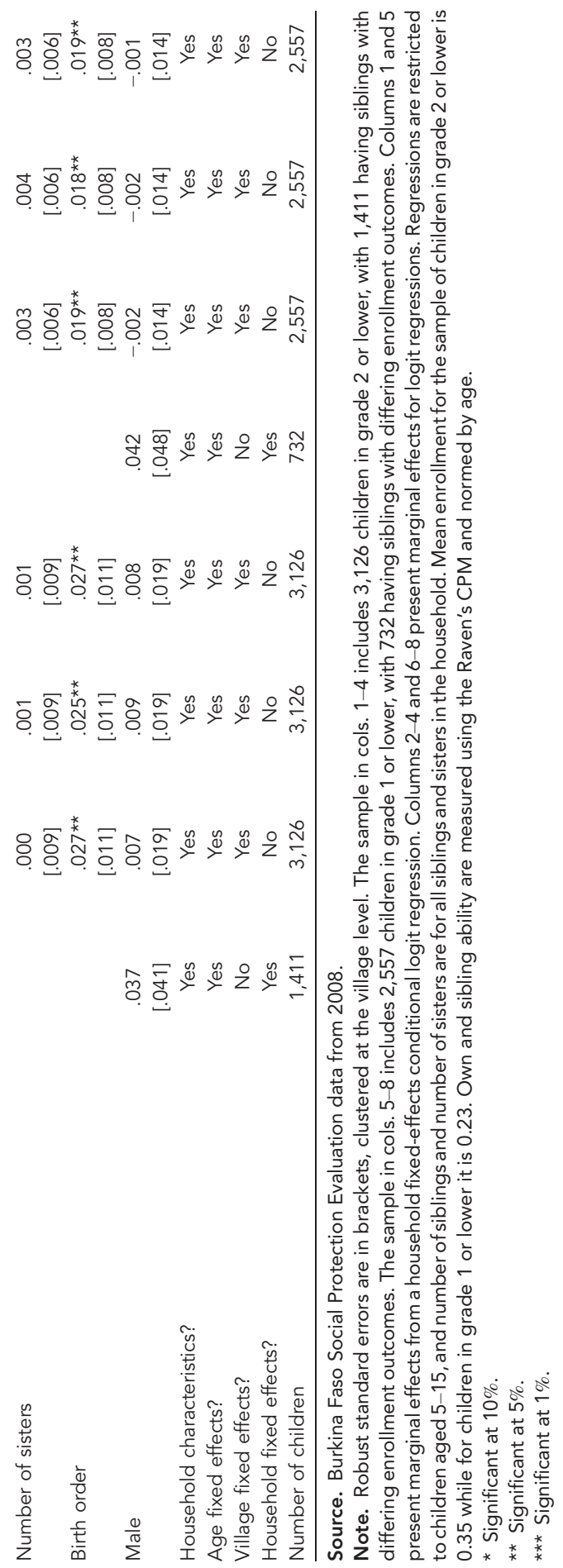


TABLE 7

MARGINAL EFFECTS FROM LOGIT AND CONDITIONAL LOGIT REGRESSIONS ESTIMATING RELATIONSHIP BETWEEN SCHOOL ENROLLMENT IN YEAR 2 AND CHILD ABILITY MEASURED IN YEAR 1

\begin{tabular}{|c|c|c|c|c|c|c|c|c|}
\hline & \multicolumn{8}{|c|}{ Dependent Variable: Current Enrollment Year 2} \\
\hline & (1) & (2) & (3) & (4) & (5) & (6) & (7) & (8) \\
\hline \multicolumn{9}{|l|}{ Own ability (Raven's } \\
\hline age-adjusted z-score) & $\begin{array}{l}.191^{\star \star} \\
{[.092]}\end{array}$ & $\begin{array}{l}.061^{\star \star} \\
{[.028]}\end{array}$ & $\begin{array}{l}.035 \\
{[.028]}\end{array}$ & $\begin{array}{c}.030 \\
{[.028]}\end{array}$ & $\begin{array}{l}.203 \\
{[.156]}\end{array}$ & $\begin{array}{c}.053 \\
{[.033]}\end{array}$ & $\begin{array}{c}.008 \\
{[.032]}\end{array}$ & $\begin{array}{l}.005 \\
{[.032]}\end{array}$ \\
\hline Highest sibling ability & & $\begin{array}{r}-.042^{\star} \\
{[.022]}\end{array}$ & & & & $\begin{array}{l}-.075^{\star \star} \\
{[.029]}\end{array}$ & & \\
\hline \multicolumn{8}{|l|}{$\begin{array}{l}\text { Higher sibling dummy ( } 1 \text { if } \\
\text { any sibling with an } \\
\text { ability }>\text { own ability) }\end{array}$} & \\
\hline \multicolumn{9}{|l|}{$\begin{array}{l}\text { One higher sibling dummy } \\
\text { ( } 1 \text { if only one sibling with }\end{array}$} \\
\hline an ability > own ability) & & & & $\begin{array}{c}-.024 \\
{[.043]}\end{array}$ & & & & $\begin{array}{c}-.056 \\
{[.048]}\end{array}$ \\
\hline \multicolumn{9}{|l|}{$\begin{array}{l}\text { Two higher sibling dummy } \\
\text { (1 if two siblings with an } \\
\text { ability }>\text { own ability) }\end{array}$} \\
\hline \multicolumn{9}{|l|}{$\begin{array}{l}\text { Three or more higher sibling } \\
\text { dummy ( } 1 \text { if three or more } \\
\text { siblings with an ability > }\end{array}$} \\
\hline own ability) & & & & $\begin{array}{l}-.131 \\
{[.095]}\end{array}$ & & & & $\begin{array}{r}-.155^{\star} \\
{[.094]}\end{array}$ \\
\hline Number of siblings & & $\begin{array}{l}-.031 \\
{[.021]}\end{array}$ & $\begin{array}{c}-.035^{\star} \\
{[.021]}\end{array}$ & $\begin{array}{l}-.031 \\
{[.022]}\end{array}$ & & $\begin{array}{l}-.026 \\
{[.022]}\end{array}$ & $\begin{array}{l}-.030 \\
{[.023]}\end{array}$ & $\begin{array}{l}-.027 \\
{[.023]}\end{array}$ \\
\hline Number of sisters & & $\begin{array}{c}.011 \\
{[.023]}\end{array}$ & $\begin{array}{l}.015 \\
{[.023]}\end{array}$ & $\begin{array}{l}.013 \\
{[.024]}\end{array}$ & & $\begin{array}{l}.004 \\
{[.029]}\end{array}$ & $\begin{array}{c}.008 \\
{[.030]}\end{array}$ & $\begin{array}{l}.005 \\
{[.030]}\end{array}$ \\
\hline Birth order & & $\begin{array}{l}.056^{\star \star} \\
{[.025]}\end{array}$ & $\begin{array}{l}.055^{\star \star} \\
{[.026]}\end{array}$ & $\begin{array}{l}.057^{\star \star} \\
{[.026]}\end{array}$ & & $\begin{array}{l}.071^{\star \star \star} \\
{[.025]}\end{array}$ & $\begin{array}{l}.070^{\star \star \star} \\
{[.026]}\end{array}$ & $\begin{array}{l}.073^{\star \star \star} \\
{[.026]}\end{array}$ \\
\hline Male & $\begin{array}{l}-.183 \\
{[.129]}\end{array}$ & $\begin{array}{l}-.072 \\
{[.045]}\end{array}$ & $\begin{array}{l}-.073 \\
{[.045]}\end{array}$ & $\begin{array}{l}-.076^{\star} \\
{[.044]}\end{array}$ & $\begin{array}{l}-.16 \\
{[.197]}\end{array}$ & $\begin{array}{l}-.074 \\
{[.057]}\end{array}$ & $\begin{array}{l}-.076 \\
{[.056]}\end{array}$ & $\begin{array}{l}-.080 \\
{[.054]}\end{array}$ \\
\hline Household characteristics? & Yes & Yes & Yes & Yes & Yes & Yes & Yes & Yes \\
\hline Age fixed effects? & Yes & Yes & Yes & Yes & Yes & Yes & Yes & Yes \\
\hline Village fixed effects? & No & Yes & Yes & Yes & No & Yes & Yes & Yes \\
\hline Household fixed effects? & Yes & No & No & No & Yes & No & No & No \\
\hline Number of children & 123 & 647 & 647 & 647 & 52 & 446 & 446 & 446 \\
\hline
\end{tabular}

Source. Burkina Faso Social Protection Evaluation data from 2008 and 2009.

Note. Robust standard errors are in brackets, clustered at the village level. Columns 1 and 5 present marginal effects from a household fixed-effects conditional logit regression. Columns $2-4$ and 6-8 present marginal effects for logit regressions. Regressions in cols. 1-4 are restricted to children aged 5-7 who were not enrolled during year 1 and in cols. 5-8 are restricted to children aged 5-6 who were not enrolled during year 1 . The sample includes 647 children aged 5-7, with 123 having siblings with differing enrollment outcomes. The sample includes 446 children aged 5-6, with 52 having siblings with differing enrollment outcomes. Mean enrollment in year 2 for the sample of children aged 5-7 (cols. 1-4) is 0.29, while for children aged 5-6 (cols. 5-8) average enrollment in year 2 is 0.27 . Sibling ability measures are for all siblings not enrolled during year 1. Own and sibling ability are measured using the Raven's CPM and normed by age (z-score).

* Significant at $10 \%$.

** Significant at $5 \%$.

$\star \star \star$ Significant at $1 \%$.

This content downloaded from 139.078.028.086 on March 19, 2019 14:34:52 PM

All use subject to University of Chicago Press Terms and Conditions (http://www.journals.uchicago.edu/t-and-c). 
aged 5-6 and not enrolled in year 1 to remove any potential concern that the not enrolled 7-year-olds are somehow different from other 7-year-old children. ${ }^{22}$ The household fixed-effects logit regressions in columns 1 and 5 indicate that within a given household, a young child with a one standard deviation higher ability measured in year 1 is, respectively, 19.1 and 20.3 percentage points more likely to be subsequently enrolled in year $2 .{ }^{23}$ The coefficient in column 1 is statistically significant at the $5 \%$ level. While the coefficient in column 5 is not statistically significant at standard levels, there are only 52 children in the regression as the household fixed-effects logit is identified only from households with multiple children aged 5-6 who were not enrolled in year 1 . Young children 5-6 years old who are not enrolled in year 1 and who have two siblings of higher ability who also are not enrolled in year 1 subsequently have a 17.1 percentage point lower probability of enrollment in year 2 (col. 8).

Fourth, in table 8, we present two alternative measures of a child's cognitive ability. To allay any concerns that transforming the Raven's scores into ageadjusted $z$-scores might have introduced bias, in columns 1-4, we estimate regressions using the Raven's raw test score. Results are consistent with those in table 3. In the household fixed-effects specification, within a given household, a child with a one standard deviation higher Raven's raw score (3.35 questions) has an 18.4 percentage point higher likelihood of being enrolled. In columns $5-8$, we also employ an alternative measure of cognitive ability, the WISC Digit Span, to examine the relationship with current enrollment and find results consistent with using the Raven's test. Children with a one standard deviation higher own WISC $z$-score have a $17-22$ percentage point higher probability of enrollment, representing $32 \%-41 \%$ of the mean enrollment level. Children with two siblings having a higher WISC $z$-score have a 14 percentage point lower probability of enrollment ( $26 \%$ of the mean level of enrollment).

\section{Conclusions}

In this article, we find strong evidence of sibling rivalry when parents make educational investment decisions in rural Burkina Faso. However, in contrast with previous research that generally focuses on easily observable demographic characteristics to measure sibling rivalry, we use measures of a child's own cognitive ability and different specifications of his siblings' abilities to test for how parents make schooling investment decisions. We examine both the

\footnotetext{
${ }^{22}$ In $2007-8,74 \%$ of children aged 5-7 were not enrolled, and of these children, $31 \%$ were then enrolled in 2008-9. For children 5-6 years old, 89\% of them were not enrolled in 2007-8, and of these children, $28 \%$ were then enrolled in the subsequent year.

${ }^{23}$ Mean enrollment in year 2 for the sample of children aged 5-7 (cols. 1-4) is 0.29 , while for children aged 5-6 (cols. 5-8) average enrollment in year 2 is 0.27 .
} 


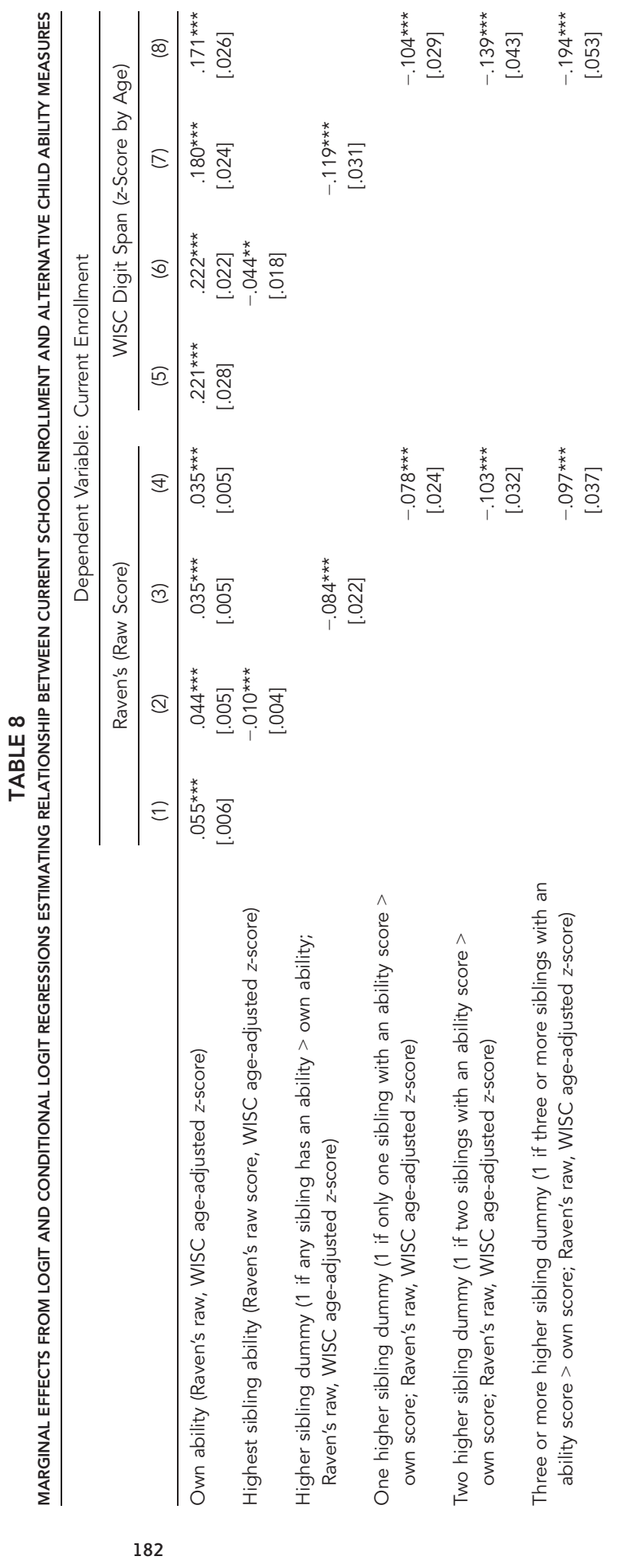

This content downloaded from 139.078.028.086 on March 19, 2019 14:34:52 PM All use subject to University of Chicago Press Terms and Conditions (http://www.journals.uchicago.edu/t-and-c). 


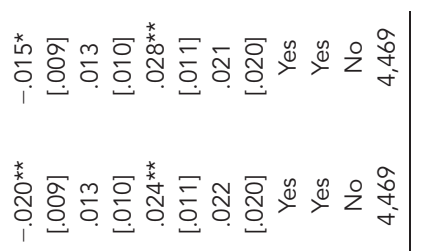

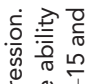
它壳 放

1.

음

in 흔

章 它

莡

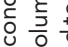

讨

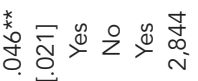

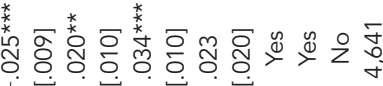

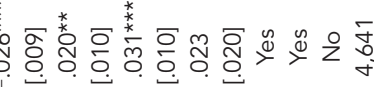

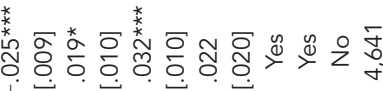


extensive margin (school enrollment and grade progression) and the intensive margin of discretionary school expenditures. Own ability has a positive effect on educational outcomes, after controlling for individual and family characteristics and when using a family fixed-effects specification. We find that within a given household a child with one standard deviation higher ability compared to the average ability of his siblings is $30 \%$ more likely to be enrolled. The impact of ability on enrollment is also large relative to the corresponding relationship between enrollment and the standard demographic variables traditionally used in the sibling rivalry literature. Estimating a regression of standardized coefficients indicates that the impact of ability is three to five times larger than for the demographic variables. Regardless of how we measure sibling ability, we find evidence of sibling rivalry, and our results are particularly strong when we consider relative measures of sibling ability. The magnitude of these impacts is large. For a child who has one higher-ability sibling, the probability of enrollment declines by $15 \%$, and having two higher-ability siblings lowers enrollment by $30 \%$. Our findings are robust to using alternative objective measures of cognitive ability and the parents' perceptions of a child's chance of future success and to addressing issues about the potential reverse causality of schooling influencing child ability measures.

Our results can likely be generalized to other developing countries that have not yet achieved universal primary or secondary education and in which parents are deciding whether to send their children to school in a given year. This article explores the context in which the decision is made during primary school, whereas in other countries the choice may occur later in a child's education. A more complete understanding of how parents make the educational investment decision is useful for policy makers. Our findings that high-ability children within a family are more likely to be enrolled and receive more educational resources suggest that parents focus on getting the most talented children through higher levels of education rather than spreading some education evenly among all of their children. If fixed costs for schooling and nonconvexities in the education production function are important factors in the decision to not invest in education equally across all children, then supply-side schooling interventions (such as the building of schools, reduction in class size, or school inputs such as textbooks or uniforms) to raise the schooling of all children and achieve the Millennium Development Goals might not be effective if they are not large enough to overcome these nonconvexities. These types of policies might raise the schooling of the more talented children rather than the schooling of all children, and so to increase overall education rates, demand-side policies, such as conditional cash transfers or school feeding programs, might be necessary. 


\section{References}

Aizer, Anna. 2004. "Home Alone: Supervision after School and Child Behavior." Iournal of Public Economics 88, no. 9:1835-48.

Ayalew, Tekabe. 2005. "Parental Preference, Heterogeneity, and Human Capital Inequality." Economic Development and Cultural Change 53, no. 2:381-407.

Becker, Gary S., and Nigel Tomes. 1976. "Child Endowments and the Quantity and Quality of Children.” Journal of Political Economy 84, no. 2 (suppl.): S143-S162.

Behrman, Jere R. 1997. "Intrahousehold Distribution and the Family." In Handbook of Population and Family Economics, vol. 1A, ed. Mark R. Rosenzweig and Oded Stark. Amsterdam: Elsevier.

Behrman, Jere R., Robert A. Pollak, and Paul Taubman. 1982. "Parental Preferences and Provision for Progeny." Iournal of Political Economy 90, no. 1:52-73.

Behrman, Jere R., Mark R. Rosenzweig, and Paul Taubman. 1994. "Endowments and the Allocation of Schooling in the Family and in the Marriage Market: The Twins Experiment." Iournal of Political Economy 102, no. 6:1131-74.

Binder, Melissa. 1998. "Family Background, Gender, and Schooling in Mexico." Iournal of Development Studies 35, no. 2:54-71.

Black, Sandra, Paul Devereux, and Kjell Salvanes. 2005. "The More the Merrier? The Effect of Family Size and Birth Order on Children's Education." Ouarterly Iournal of Economics 120, no. 2:669-700.

Borghans, Lex, Angela Lee Duckworth, James A. Heckman, and Bas ter Weel. 2008. "The Economics and Psychology of Personality Traits." Working Paper no. 13810, National Bureau of Economic Research, Cambridge, MA.

Chamberlain, Gary. 1980. "Analysis of Covariance with Qualitative Data.” Review of Economic Studies 47, no. 1:225-38.

Dammert, Ana. 2010. "Siblings, Child Labor, and Schooling in Nicaragua and Guatemala." Lournal of Population Economics 23, no. 1:199-224.

Edmonds, Eric. 2007. "Understanding Sibling Differences in Child Labor." Iournal of Population Economics 19, no. 4:795-821.

Emerson, Patrick M., and Andre Portela Souza. 2008. "Birth Order, Child Labor, and School Attendance in Brazil." World Development 36, no. 9:1647-64.

Garg, Ashish, and Jonathan Morduch. 1998. "Sibling Rivalry and the Gender Gap: Evidence from Child Health Outcomes in Ghana." Iournal of Population Economics 11, no. 4:471-93.

Glewwe, Paul, and Michael Kremer. 2006. "Schools, Teachers, and Education Outcomes in Developing Countries." In Handbook on the Economics of Education, ed. Eric Hanushek and Finis Welch. Amsterdam: North-Holland.

Glick, Peter, and David E. Sahn. 2010. "Early Academic Performance, Grade Repetition, and School Attainment in Senegal: A Panel Data Analysis.” World Bank Economic Review 24, no. 1:93-120.

Kazianga, Harounan. 2004. "Schooling Returns for Wage Earners in Burkina Faso: Evidence from the 1994 and 1998 National Surveys.” Discussion Paper no. 892, Economic Growth Center, Yale University.

- 2006. "Motives for Household Private Transfers in Burkina Faso." Lournal of Development Economics 79, no. 1:73-117. 
Kessler, Daniel. 1991. "Birth Order, Family Size, and Achievement: Family Structure and Wage Determination.” Iournal of Labor Economics 9, no. 4:413-26.

Kim, Hisam. 2005. "Parental Investment between Children with Different Abilities." Unpublished manuscript, Department of Economics, University of WisconsinMadison.

Morduch, Jonathan. 2000. "Sibling Rivalry in Africa." American Economic Review Papers and Proceedings 90, no. 2:405-9.

Ota, Masako, and Peter Moffatt. 2007. "The Within-Household Schooling Decision: A Study of Children in Rural Andhra Pradesh." Iournal of Population Economics 20, no. 1:223-39.

Parish, William, and Robert Willis. 1993. "Daughters, Education, and Family Budgets: Taiwan Experiences.” Lournal of Human Resources 28, no. 4:863-98.

Raven, John E., John C. Raven, and John H. Court. 1998. Manual for Raven's Progressive Matrices and Vocabulary Scales, sec. 1, General Overview. Oxford: Oxford Psychologists Press.

Rosenzweig, Mark R., and T. Paul Schultz. 1982. "Market Opportunities, Genetic Endowments, and Intrafamily Resource Distribution: Child Survival in Rural India." American Economic Review 72, no. 4:803-15.

Schultz, T. Paul. 2004. "Evidence of Returns to Schooling in Africa from Household Surveys: Monitoring and Restructuring the Market for Education." Journal of African Economies 13, no. 2 (suppl.): 95-148.

Strauss, John, and Duncan Thomas. 1995. "Human Resources: Empirical Modeling of Household and Family Decisions." In Handbook of Development Economics, vol. 3A, ed. Jere Behrman and T. N. Srinivasan. Amsterdam: Elsevier/NorthHolland.

Wechsler, David. 1974. Wechsler Intelligence Scales for Children-Revised. New York: Psychological Corp. 